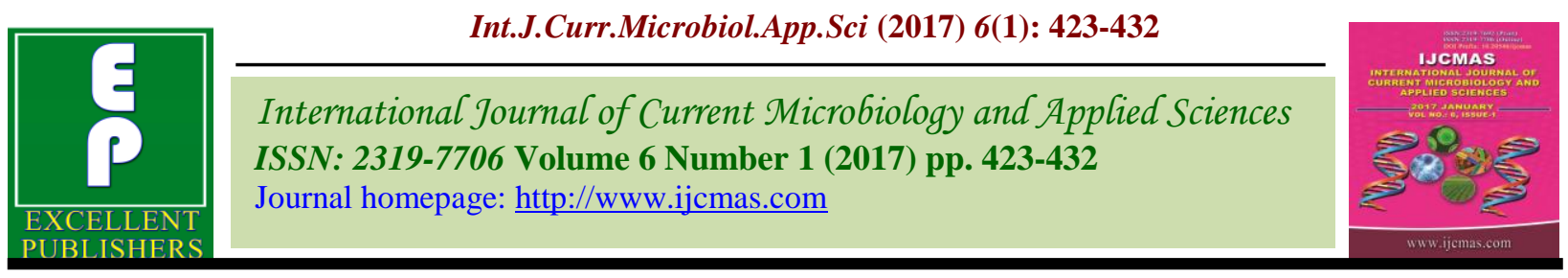

Original Research Article

http://dx.doi.org/10.20546/ijcmas.2017.601.051

\title{
Study of Antibacterial Efficacy of Methanolic and Aqueous Leaf Extracts of Scoparia dulcis on Some Human Pathogenic Bacteria
}

\author{
Sophy Jose* and M.P. Sinha \\ Department of Zoology, Ranchi University, Ranchi-834008, Jharkhand, India \\ *Corresponding author
}

A B S T R A C T

Keyw ords

Scoparia dulcis is a well known traditional medicinal plant used in various indigenous systems of medicine. It is widely distributed throughout India. The present study provides phytochemical and antimicrobial details of the methanolic and aqueous leaf extracts of Scoparia dulcis against clinically important human pathogens viz. Staphylococcus aureus,

Scoparia dulcis, Pathogens, Antibacterial activity, Extracts.

\section{Article Info}

\section{Accepted:}

18 December 2016 Available Online:

10 January 2017
Proteus mirabilis, Salmonella typhi, Vibrio cholerae and Bacillus subtilis. The phytochemical analysis carried out revealed the presence of flavanoids, glycosides, alkaloids, tannins, steroids and many other metabolites and the absence saponins. Minimum inhibitory concentration (MIC) assay was determined for the extract. The methanolic and aqueous extract showed toxicity against all the bacteria, V. Chlolerae and P.mirabilis being highly susceptible with a zone of inhibition of $4 \mathrm{~mm}$ at $10 \mathrm{mg} / \mathrm{ml}$ and 2 $\mathrm{mm}$ at $10 \mathrm{mg} / \mathrm{ml}$ respectively in agar diffusion method. The broth dilution method showed more pronounced antimicrobial activity through $100 \%$ inhibition for all the pathogens in the range of $1-32 \mathrm{mg} / \mathrm{mL}$ concentration. The MIC for S.typhi and B.subtilis in methanolic solution was $32 \mathrm{mg} / \mathrm{mL}$, for P.mirabilis $16 \mathrm{mg} / \mathrm{mL}$, for S.aureus $8 \mathrm{mg} / \mathrm{mL}$ and V.cholerae $1 \mathrm{mg} / \mathrm{mL}$. The MIC for S.aureus and V.cholerae in aqueous solution was $16 \mathrm{mg} / \mathrm{mL}$, for P.mirabilis $4 \mathrm{mg} / \mathrm{mL}$, S. typhi $8 \mathrm{mg} / \mathrm{mL}$ and for B. subitlis $32 \mathrm{mg} / \mathrm{mL}$.

\section{Introduction}

Chemical materials obtained from plants have recently become of great interest due to their versatile usefulness (Jose and Sinha, 2016). Medicinal plants are the richest bio-resources of drugs of traditional systems of medicine, modern medicines, nutraceuticals, food supplements, folk medicines, pharmaceutical intermediates and chemical entities for synthetic drugs (Ncube et al., 2008). The use of simple extracts of plant parts and phytochemicals, of known antimicrobial properties, can be of great significance in the curative treatments. Due to indiscriminate use of commercial antimicrobial drugs commonly employed in the treatment of infectious diseases, there have been increasing numbers of multiple resistances in human pathogenic microorganisms in recent years (Davies, 1994). This has compelled scientists to search for new antimicrobial substances from various sources like the medicinal plants (I.Wu.M.W., Duncan and Okunji. 1999). Secondary metabolites from higher plants serve as defence agents against invading micro-organisms (Balandrin et al., 1985). Medicinal properties of plants are due to the active chemical constituents present in different parts of the plant (Palombo, 2006). 
Five common human pathogenic bacteria under consideration are Salmonella typhi, Proteus mirabilis, Staphylococcus aureus, Bacillus subtilis and Vibrio cholera. S. typhi is causative agent of typhoid (Wain et al., 2015). $P$. mirabilis is a Gram negative, facultatively anaerobic rod-shaped bacterium. It shows urease activity and swarming motility. P.mirabilis causes almost all of Proteus infections in humans. It is widely distributed in soil and water and is a causative agent of diseases like urethitis, prostatitia, and pneumonia etc., (Burall et al., 2004). Vibrio cholerae is a gram- negative commashaped bacterium. Some strains of $V$. cholerae cause the disease cholera. ("Laboratory Methods for the Diagnosis of Vibrio cholerae"). Staphylococcus aureus is a gram positive coccal bacteriam that is a member of the Firmicutes, and is frequently found in the nose, respiratory tract and on the skin. Although $S$. aureus is not always pathogenic, it is a common cause of skin infections such as abscesses, respiratory infections such as sinusitis and food poisoning (Bowersox, 1999). Bacillus subtilis, known also as the hay bacillus or grass bacillus, is a Gram-positive, catalase-positive bacterium, found in soil and the gastrointestinal tract of ruminants and humans. B. subtilis is only known to cause disease in patients who are weak in immunity. (Ryan; Ray, eds (2004)).

Scoparia dulcis is an annual erect herb distributed throughout tropical and subtropical regions of India, America, Brazil, West Indies, and Myanmar (Mukherjee, 2003). The whole plant is used for ailments like diarrhea, stomach-ache, kidney stones, kidney problems, and fever(Jain and Srivastava, 2005). Earlier studies also suggested that methanol extract of Scoparia dulcis has hypoglycemic activities and is used for the treatment of Diabetes Mellitus (Mishra et al.,). Many more therapeutic potentialities of S.dulcis have to be determined as it is an easily available and highly potential medicinal plant. Therefore, present study was undertaken to test the antibacterial activity of $S$. dulcis against some common human pathogenic bacteria.

\section{Materials and Methods}

Collection of plant material: The fresh and tender leaves of S.dulcis were collected, dried in a shade under room temperature for six days and then by using electric grinder it was crushed into coarse powdery substance. The coarse powdery substance was dried again and was then sieved to get fine powder using the fine plastic sieve, which was then stored in an air tight bottle in the laboratory until required (Sushmita Choudhury et al.,).

\section{Extract Preparation}

$50 \mathrm{~g}$ of S.dulcis leaf powder was extracted by soxhlet using methanol and water separately. The extract obtained was filtered, concentrated after drying in rotary flash evaporator maintained at $45^{\circ} \mathrm{c}$., percentage yield of each extract was calculated and the dried extract was stored in air tight containers at room temperature for further studies.

Phytochemical analyses: Freshly prepared extract of the powdered leaves were subjected to phytochemical analyses to find the presence of the following phyto constituents such as flavanoids, alkaloids, carbohydrates, glycosides, polysaccharides, tannins, saponins, steroids, proteins, lipids, oils by standard methods ( Trease and Evans, 2002; Sofowara, 2008).

\section{Anti-bacterial analyses}

Test Microorganisms: The organisms namely Staphylococcus aureus, Salmonella typhi, Vibrio cholera, Bacillus subtilis and 
Proteus mirabilis used during the present experiment were procured from Institute of Microbial (IMTECH), Chandigarh, India.

Concentrations screened: $25 \mu \mathrm{g}, 50 \mu \mathrm{g}, 100$ $\mu \mathrm{g}, 250 \mu \mathrm{g}, 500 \mu \mathrm{g}, 1000 \mu \mathrm{g}$ for agar disc diffusion method and for broth dilution method $1 \mathrm{mg} / \mathrm{ml}, 2 \mathrm{mg} / \mathrm{ml}, 4 \mathrm{mg} / \mathrm{ml}, 8 \mathrm{mg} / \mathrm{ml}$, $16 \mathrm{mg} / \mathrm{ml}$ and $32 \mathrm{mg} / \mathrm{ml}$.

\section{Agar diffusion method}

Media Used: Peptone-10 g, NaCl-10g and Yeast extract 5g, Agar $20 \mathrm{~g}$ in $1000 \mathrm{ml}$ of distilled water. Initially, the stock cultures of bacteria were revived by inoculating in broth media and grown at $37^{\circ} \mathrm{C}$ for $18 \mathrm{hrs}$. The agar plates of the above media were prepared and wells were made in the plate $(25 \mu \mathrm{g}, 50 \mu \mathrm{g}$, $100 \mu \mathrm{g}, 250 \mu \mathrm{g}, 500 \mu \mathrm{g}$, and $1000 \mu \mathrm{g}$ ) Each plate was inoculated with $18 \mathrm{~h}$ old cultures $(100 \mu \mathrm{L}, 104 \mathrm{cfu})$ and spread evenly on the plate. After $20 \mathrm{~min}$, the wells were filled with different concentrations of samples. The control wells were filled with Ciprofloxacin along with solvent. All the plates were incubated at $37^{\circ} \mathrm{C}$ for $24 \mathrm{~h}$ and the diameter of inhibition zones were noted (Threlfall et al., 1999).

\section{Broth dilution method}

Media Used: Peptone-10 g, NaCl-10g and Yeast extract $5 \mathrm{~g}$, in $1000 \mathrm{ml}$ of distilled water. Initially, the stock cultures of bacteria were revived by inoculating in broth media and grown at $37^{\circ} \mathrm{C}$ for $18 \mathrm{hrs}$. The tubes containing above media were prepared, autoclaved and respective concentrations of the sample were added. Each tube was inoculated with $18 \mathrm{~h}$ old cultures $\left(100 \mu \mathrm{l}, 10^{4}\right.$ cfu). A control tube with inoculums and without any sample was prepared along with a sterile media tube as blank. All the tubes were incubated at $37^{\circ} \mathrm{C}$ on a shaker with 140 rpm for $24 \mathrm{~h}$ and the growth was measured at $660 \mathrm{~nm}$ (Walker, 2000). The \% of inhibition was calculated by using the formula below.

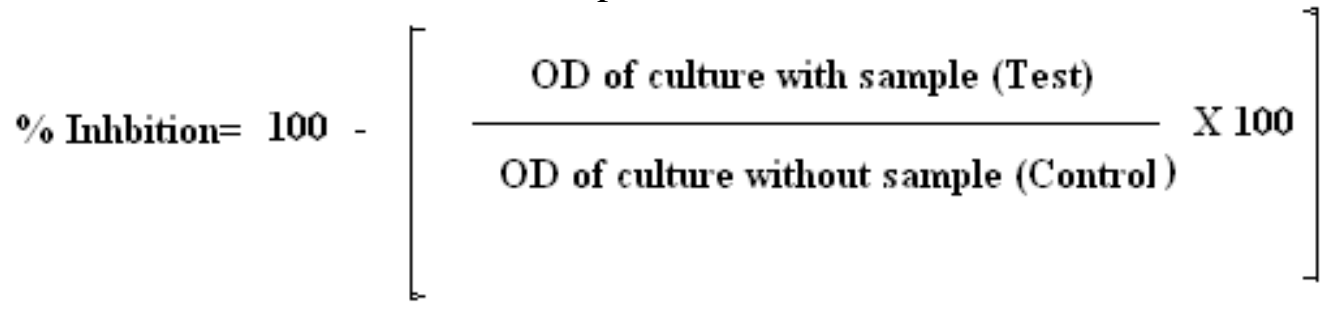

\section{Results and Discussion}

Investigation on Physicochemical analysis of leaves of diverse medicinal plants has been studied by many workers that exposed the presence of phytochemicals like carbohydrates, glycosides, alkaloids, tannins etc., in them (Ayoola et al., 2008, Jigna Parekh, and Sumitra Chanda, 2006). The results of the evaluation of phytochemical screening of methanolic extracts of Scoparia dulcis revealed the presence of carbohydrates, glycosides, polysaccharides, proteins, steroids, alkaloids, triterpenoids, tannins, lipids, oils, and flavanoids and the absence of saponins. These constituents are responsible for the curative nature of Scoparia dulcis against ,diarrhea, stomach-ache, kidney stones, kidney problems, and fever, hypoglycemic activities and Diabetes Mellitus (Mishra et al., Palombo, 2006) etc. which could make the plant useful for treating different diseases and having a potential of providing valuable and safe drugs which will be beneficial for human utilization.

\section{Antibacterial assay}

The antibacterial efficacy of the extracts of $S$. dulcis leaves was quantitatively measured on 
the basis of inhibition zone (in $\mathrm{mm}$ ) and the results are shown in Table 2 following the agar disc diffusion method, and minimum inhibitory concentration by broth dilution method. Antibacterial activity of Ciprofloxacin was also tested against the same pathogenic bacteria in agar well diffusion method (Table -3 and figure-2) to compare antibacterial efficacy of $S$. dulcis leaf extracts.

\section{Agar diffusion method}

In the present investigation the methanolic and aqueous extracts of S.dulcis were found to be effective against all the pathogens. When the above pathogens were screened by agar disc diffusion method the zone of inhibition (ZOI) observed for the methanolic extract was in the range $2-4 \mathrm{~mm}$ at $10 \mathrm{mg} / \mathrm{mL}$ concentration of the extract.

Table.1 Proximate Phytochemical composition of Methanolic and aqueous extracts of S.dulcis

\begin{tabular}{|l|c|c|}
\hline Phytochemicals & Methanolic & Aqueous \\
\hline Carbohydrates & + & + \\
\hline Glycosides & + & + \\
\hline Polysaccharides & - & - \\
\hline Proteins & + & + \\
\hline Alkaloids & + & + \\
\hline Steroids & + & + \\
\hline Triterpenes & + & - \\
\hline Flavanoids & + & + \\
\hline Tannins & + & - \\
\hline Lipid & + & + \\
\hline Oils & + & - \\
\hline Saponins & - & - \\
\hline
\end{tabular}

Table.2 Proximate Phytochemical composition of Methanolic and aqueous extracts of S.dulcis

\begin{tabular}{|l|l|l|l|l|l|l|l|l|l|l|}
\hline \multirow{3}{*}{ concentration } & \multicolumn{2}{|c}{ S. typhi } & \multicolumn{2}{c|}{ S. aureus } & \multicolumn{2}{c|}{ B. subtilis } & \multicolumn{2}{c|}{ V. cholerae } & \multicolumn{2}{c|}{ P. mirabilis } \\
\cline { 2 - 10 } & Aq & Met & Aq & Met & Aq & Met & Aq & Met & Aq & Met \\
\hline $25 \mu \mathrm{g}$ & 0 & 0 & 0 & 0 & 0 & 0 & 0 & 0 & 0 & 0 \\
$50 \mu \mathrm{g}$ & 0 & 0 & 0 & 0 & 0 & 0 & 0 & 0 & 0 & 0 \\
$100 \mu \mathrm{g}$ & 0 & 0 & 0 & 0 & 0 & 0 & 0 & 0 & 0 & 0 \\
$250 \mu \mathrm{g}$ & 0 & 0 & 0 & 0 & 0 & 0 & 0 & 0 & 0 & 0 \\
$500 \mu \mathrm{g}$ & 0 & 0 & 0 & 0 & 0 & 0 & 0 & 0 & 0 & 0 \\
$1000 \mu \mathrm{g}$ & 0 & 0 & 0 & 0 & 0 & 0 & 0 & 4 & 0 & 2 \\
$\mathrm{MIC}(\mathrm{mg} / \mathrm{ml})$ & NF & NF & NF & NF & NF & NF & NF & 1000 & NF & 1000 \\
& & & & & & & & & & \\
\hline
\end{tabular}


Int.J.Curr.Microbiol.App.Sci (2017) 6(1): 423-432

Table.3 MIC of Ciprofloxacin against the test organisms

\begin{tabular}{|l|l|l|l|l|l|}
\hline Concentration & \multicolumn{1}{|c|}{ S. typhi } & \multicolumn{1}{|c|}{ S. aureus } & B. subtilis & V. cholerae & P. mirabilis \\
\hline $25 \mu \mathrm{g}$ & 27 & 25 & 20 & 30 & $*$ \\
$50 \mu \mathrm{g}$ & 31 & 28 & 24 & 31 & $*$ \\
$100 \mu \mathrm{g}$ & 35 & 31 & 27 & 34 & $*$ \\
$250 \mu \mathrm{g}$ & 38 & 34 & 30 & 36 & $*$ \\
$500 \mu \mathrm{g}$ & 40 & 36 & 36 & 38 & $*$ \\
$1000 \mu \mathrm{g}$ & $*$ & $*$ & $*$ & $*$ & $*$ \\
$\mathrm{MIC}(\mathrm{mg} / \mathrm{ml})$ & 25 & 25 & 25 & 25 & 25 \\
\hline
\end{tabular}

Fig.1 Zone of Inhibition of methanolic and aqueous leaf extracts of S.dulcis against different bacteria

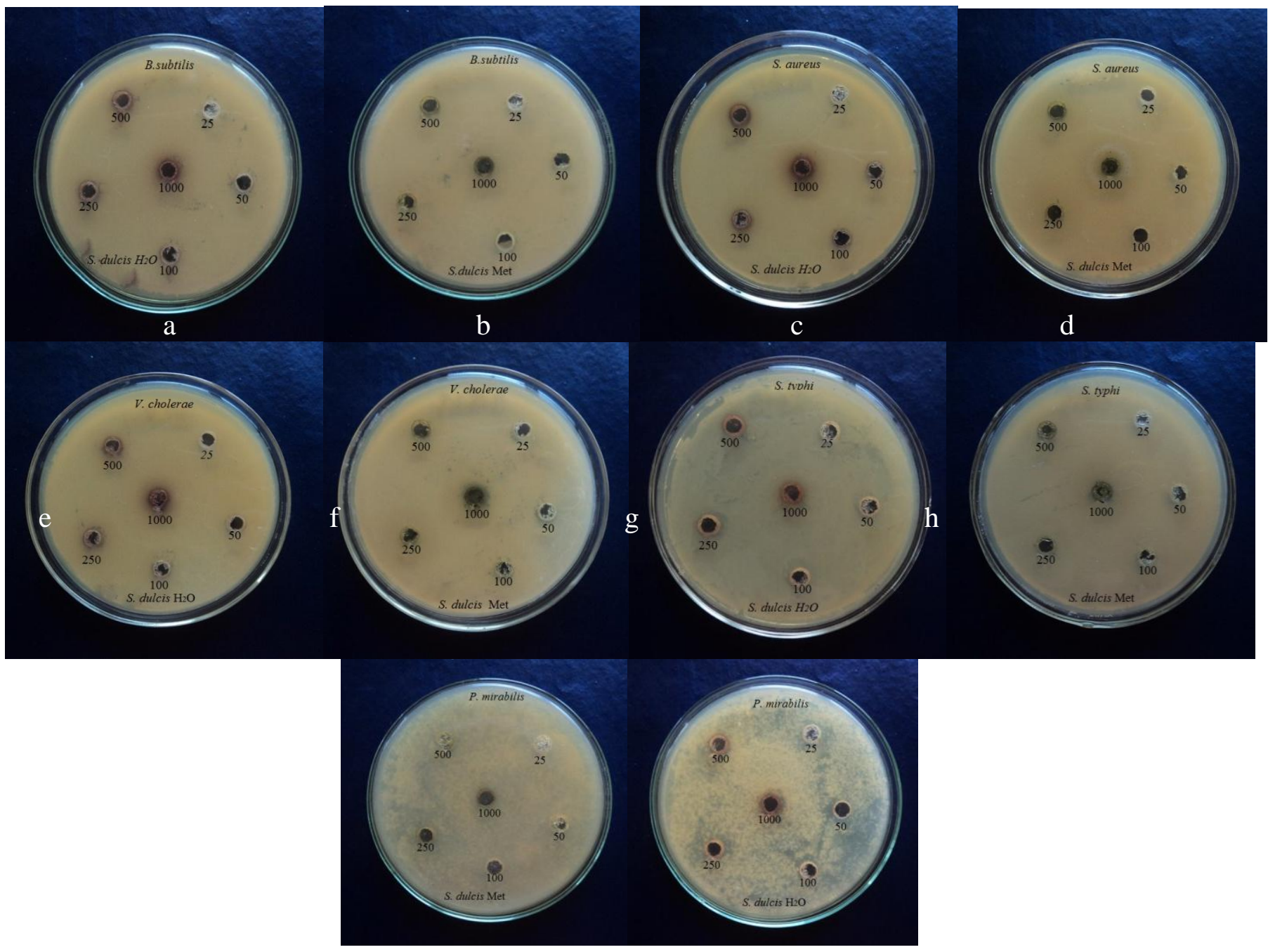


Fig.2 Zone of Inhibition of Ciprofloxacin against different bacteria

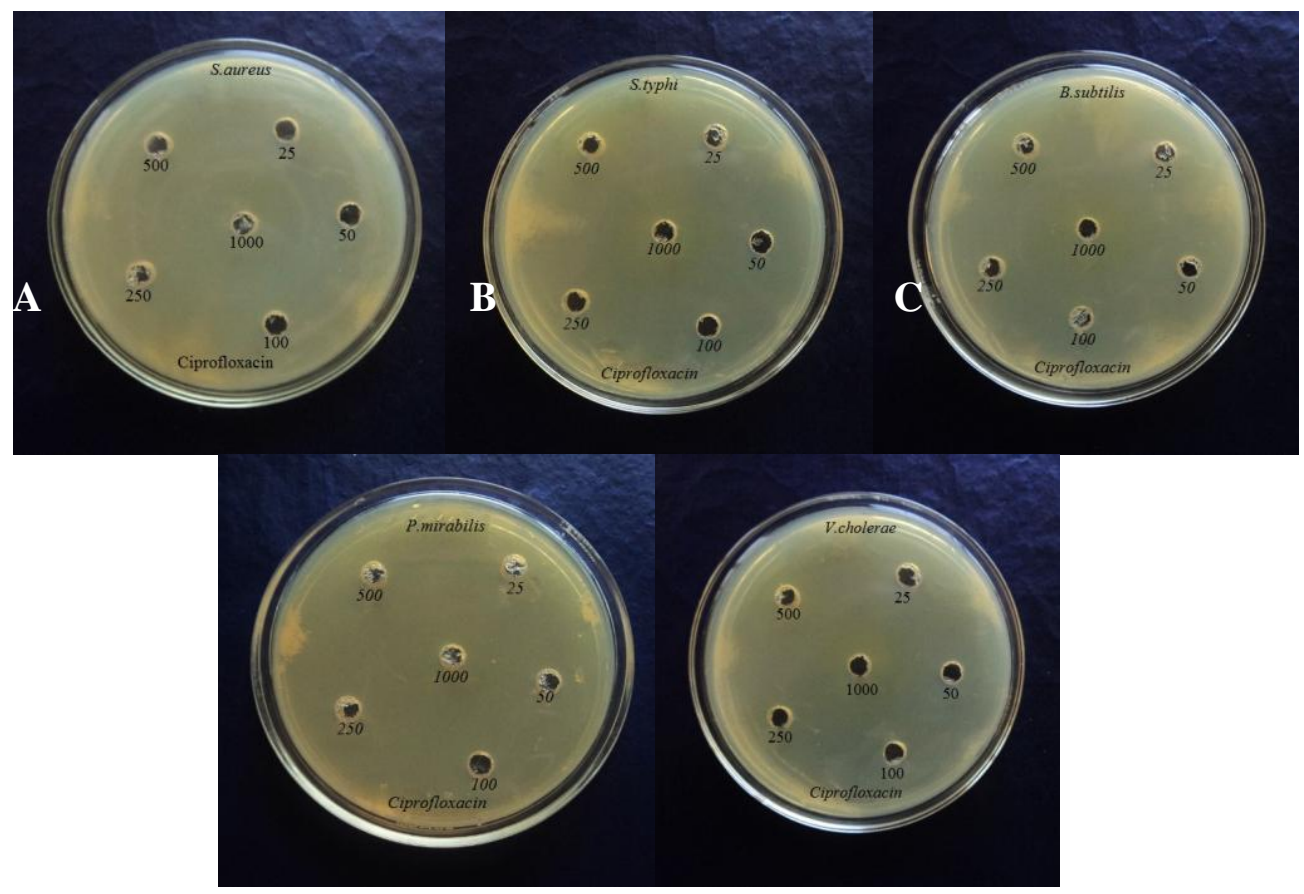

Fig.3 \% Inhibition of S. dulcis leaf extract against S. aureus in broth dilution method

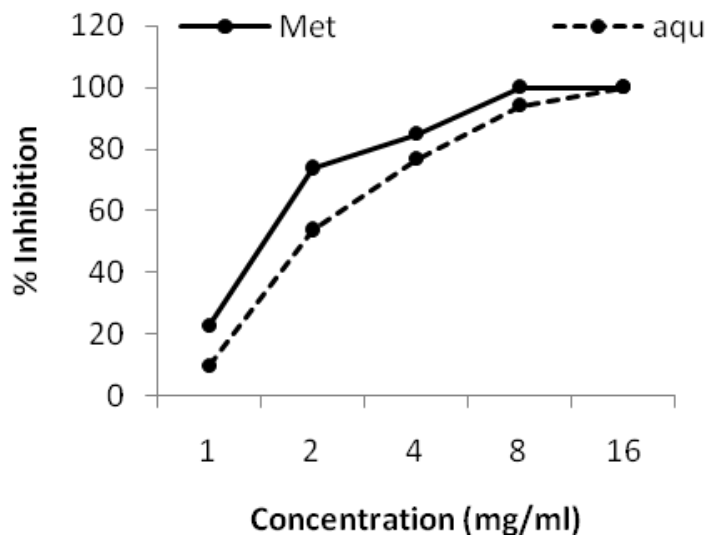


Fig.4 \% Inhibition of S. dulcis leaf extract against V.cholerae in broth dilution method

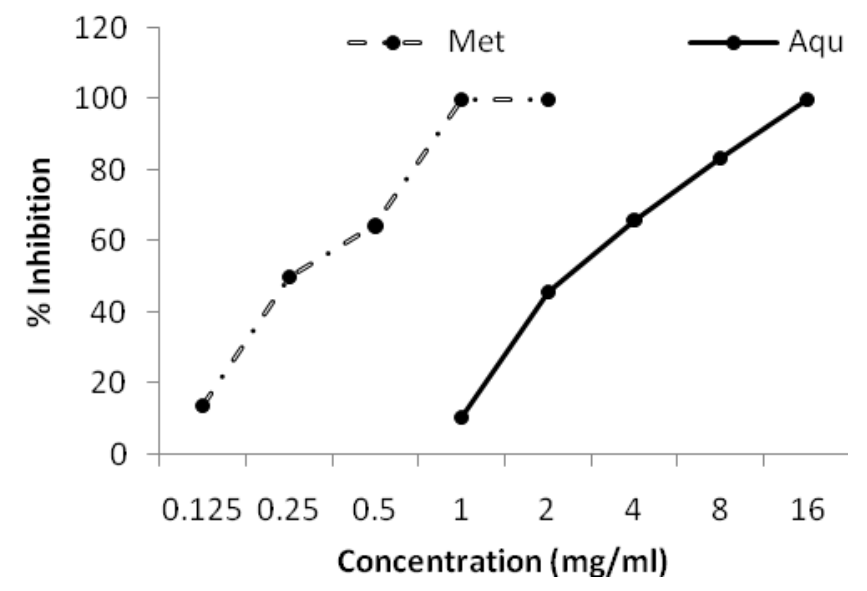

Fig.5 \% Inhibition of $S$. dulcis leaf extract against P.mirabilis in broth dilution method

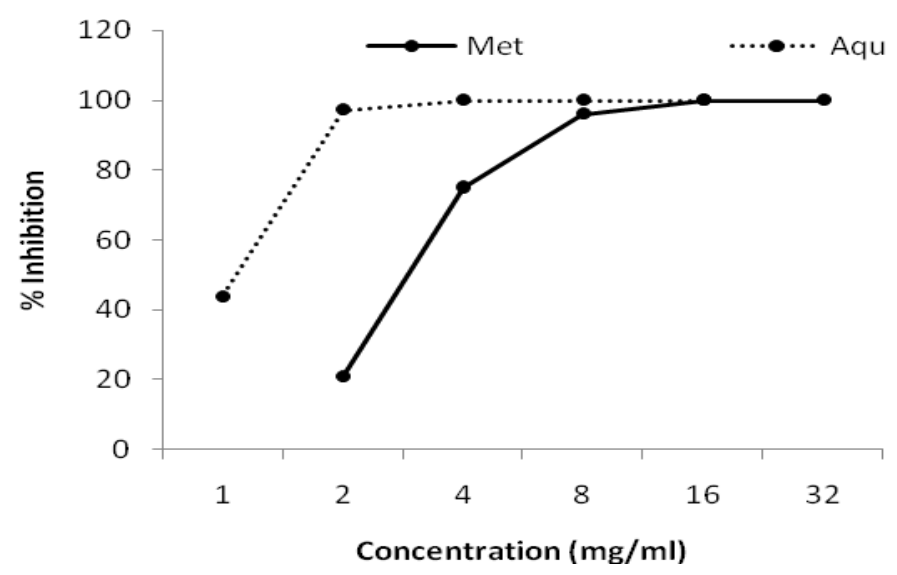

Fig.6 \% Inhibition of $S$. dulcis leaf extract against S.typhi in broth dilution method.

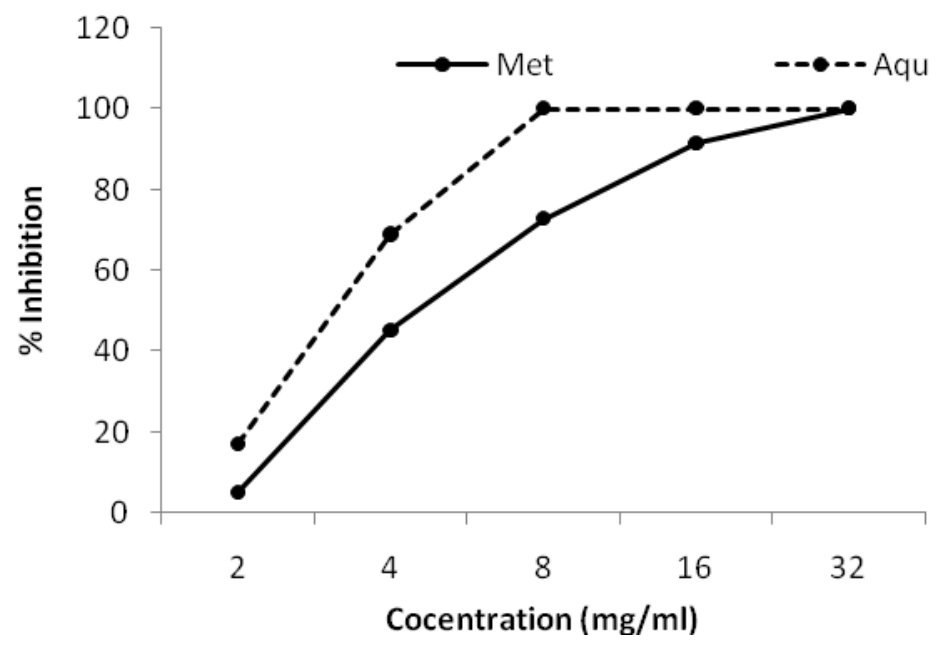


Fig.7 \% Inhibition of S. dulcis leaf extract against B.subitlis in broth dilution method.

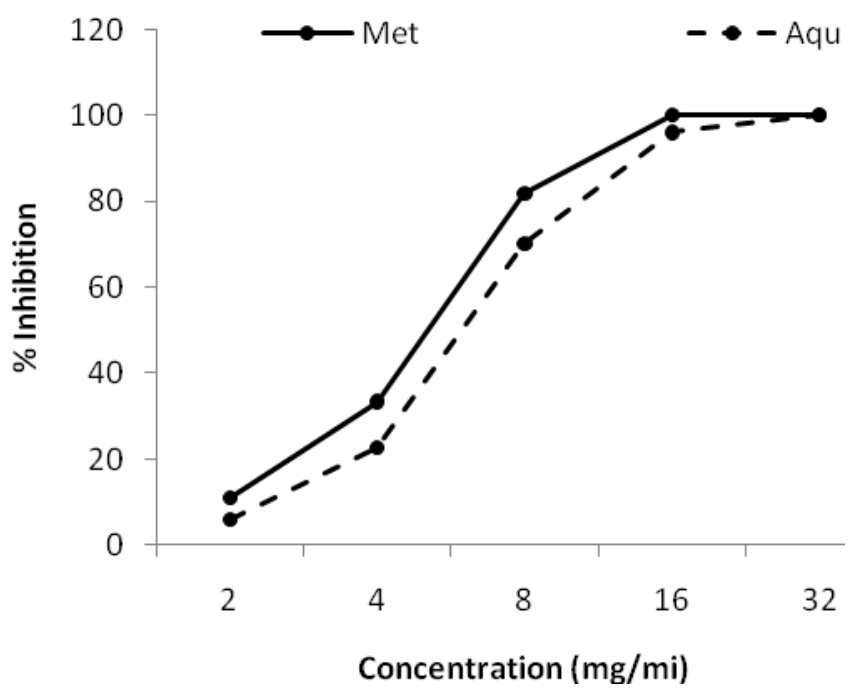

V. Cholerae was found to be highly susceptible as it showed an inhibition zone of $4 \mathrm{~mm}$ at $1000 \mu \mathrm{g}$ concentration whereas P.mirabilis was comparatively less sensitive by showing $2 \mathrm{~mm}$ ZOI at $10 \mathrm{mg} / \mathrm{mL}$ concentration. B.subtilis, S.typhi and S.aureus did not show any zone of inhibition reflecting their insensitiveness towards the methanolic extract of the leaf. None of the test bacteria showed any zone of inhibition towards the aqueous leaf extract of the S.dulcis reflecting their insensitiveness towards the aqueous extract of the leaf.

\section{Broth dilution method}

The broth dilution method showed more pronounced antimicrobial activity through $100 \%$ inhibition for all the pathogens in the range of $1-32 \mathrm{mg} / \mathrm{mL}$ concentration. The MIC for S.typhi and B.subtilis in methanolic solution was $32 \mathrm{mg} / \mathrm{mL}$ (Fig. $1 . \mathrm{h} \& \mathrm{~b}$ ), for P.mirabilis $16 \mathrm{mg} / \mathrm{mL}$ (Fig.1. i), for S.aureus $8 \mathrm{mg} / \mathrm{mL}$ (Fig 1.d) and V.cholerae $1 \mathrm{mg} / \mathrm{mL}$ (Fig.1.f) The MIC for S.aureus and V.cholerae in aqueous solution was $16 \mathrm{mg} / \mathrm{mL}$ (Fig.1.c\&e), for P.mirabilis $4 \mathrm{mg} / \mathrm{mL}$ (Fig.1.j), S. typhi $8 \mathrm{mg} / \mathrm{mL}$ (Fig.1.g) and for B.subitlis $32 \mathrm{mg} / \mathrm{mL}$ (fig. $1 . \mathrm{a})$.
In conclusion, the present study suggests antibacterial property of methanolic and aqueous leaf extracts of Scoparia dulcis, which inhibits the growth of pathogenic bacteria S. aureus, V. Cholerae, B. Subtilis S.typhi and P.mirabilis causative agent food poisoning boils, abscesses, wound infection, cholera, pneumonia, toxic shock syndrome, typhoid fever and urethitis, cystitis, pylonephritis, prostatitis and pneumonia disease. It can be used as new drug for therapy, and it can be convincingly stated the methanolic and aqueous leaf extracts of S.dulcis are potential antibacterial agents and can be used to prepare new antibiotics to cure various ailments caused by bacteria.

\section{Acknowledgements}

The authors acknowledge the facilities provided by the Department of Zoology, Ranchi University, Ranchi.

\section{References}

Ayoola, G.A., H.A.B. Coker, S.A. Adesegun, A.A. Adepoju-Bello, K. Obaweya1, E.C. Ezennia, T.O. Atangbayila. 2008. Phytochemical Screening and 
Antioxidant Activities of Some Selected Medicinal Plants Used for Malaria Therapy in South-western Nigeria, Trop. J. Pharmaceutical Res., 7(3): 1019-1024.

Balandrin, M.F., Kjocke, A.J., Wurtele, E. 1985. Natural plant chemicals: sources of industrial and mechanical materials. Sci., 228: 1154- 116

Bowersox, John.1999. "Experimental Staph Vaccine Broadly Protective in Animal Studies". NIH. Archived from the original on 5 May 2007. Retrieved 28 July2007.

Davies. 1994. J. Inactivation of antibiotics and the dissemination of resistance genes. Sci., 264: 375-382.

I.Wu.M. W., A.R. Duncan and C.O. Okunji. 1999. J. ASHA Press Alexandra V.A. pp. $457-462$

Jain, S.K., Srivastava, S. 2005. Traditional uses of some Indian plants among the islanders of Indian Ocean. Indian $J$. Tradit. Knowl., 4: 345-57.

Jigna Parekh, and Sumitra Chanda. Antibacterial and phytochemical studies on twelve species of Indian medicinal plants, African J. Biomed. Res., Vol. 10: $175-181$.

Laboratory Methods for the Diagnosis of Vibrio cholerae. Retrieved 29 October 2013.). Centre for Disease Control.

Laurel, S., Burall, Janette, M., Harro, Xin Li, C. Virginia Lockatell, Stephanie, D. Himpsl, J. Richard Hebel, David E. Johnson, Harry, L.T. Mobley. 2004. Proteus mirabilis Genes That Contribute to Pathogenesis of Urinary Tract Infection: Identification of 25 Signature-Tagged Mutants Attenuated at Least 100-Fold. Infect. Immunity, p. 2922-2938.

Mishra, M.R., A. Pradhan, A.K. Behera and S. Jha. Antidiabetic and
Antioxidant Activity of Scoparia dulcis Linn.

Mukherjee, P.K.2003. Exploring botanicals in Indian system of medicineRegulatory perspectives. Clin Res Reg Aff., 20: 249-64.

Ncube, N.S., Afolayan, A.J., Okoh, A.I. 2008. Assessment techniques of antimicrobial properties of natural compounds of plant origin: current methods and future trends. African J. Biotechnol., 7(12): 1797-1806.

Palombo, E.A. 2006. Phytochemicals from traditional medicinal plants used in the treatment of diarrhoea: modes of action and effects on intestinal function. Phytother. Res., 20(9): 717-724.

Ryan, K.J., Ray, C.G, eds. 2004. Sherris Medical Microbiology (4th ed.). McGraw Hill, ISBN 0-8385-8529-9.

Sofowora, A. 2008. Screening Plants for Bioactive Agents. In: Medicinal Plants and Traditional Medicinal in Africa. 3rd Ed. Spectrum Books Ltd, Sunshine House, Ibadan, Nigeria. p. 134.

Sophy Jose and M.P. Sinha. 2016. Phytochemistry and antibacterial efficacy of Schleichera oleosa on some human pathogenic bacteria. J. The EcoScan Special issue, Vol. IX: 00-00.

Sushmita Choudhury, Latika sharan and M.P. Sinha. antibacterial efficacy and phytochemistry of methanolic leaf extracts of mangifera indica linn.

Threlfall, E.J., Fisher, I.S.T., Ward, L., Tschape H. \& Gerner-smidt, P. 1999. Harmonization of antibiotic susceptibility testing for Salmonella: Results of a study by 18 national reference laboratories within the European Union-funded Enter-Net group. Microb. Drug Resist., 5: 195199.

Trease and Evan. 2002. Qualitative Phytochemical Screening and In VitroAntimicrobial effects of Methanol 
Stem Bark Extract of Ficus Thonningii (Moraceae).

Wain, J., Hendriksen, R.S., Mikoleit, M.L., Keddy, K.H., Ochiai, R.L. 2015. "Typhoid fever.". Lancet, 385(9973): 1136-45. doi:10.1016/s01406736(13)62708-7. PMID 25458731
Walker, R.D. 2000. Antimicrobial susceptibility testing and interpretation of results. In: Antimicrobial Therapy in Veterinary Medicine, Prescott J.F., Baggot J.D., Walker R.D., eds. Ames, IA, Iowa State University Press, 12-26.

\section{How to cite this article:}

Sophy Jose and M.P. Sinha. 2017. Study of Antibacterial Efficacy of Methanolic and Aqueous Leaf Extracts of Scoparia dulcis on Some Human Pathogenic Bacteria. Int.J.Curr.Microbiol.App.Sci. 6(1): 423-432. doi: http://dx.doi.org/10.20546/ijcmas.2017.601.051 